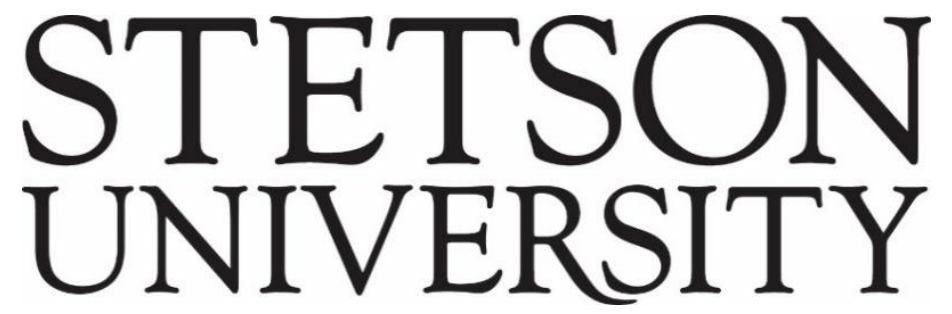

Voices of Reform: Educational Research to Inform and Reform

Volume $3 \bullet$ Issue $1 \bullet$ Article 1

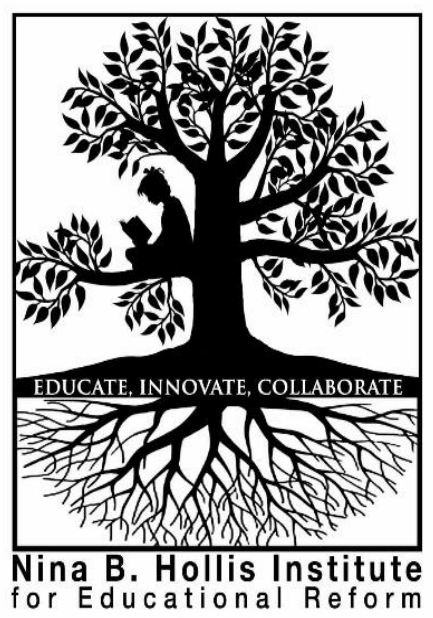

May 2020

\title{
Black Church/School Partnerships: The Role of Fictive Kin Relationships
}

\author{
Katherine A. Curry \\ Oklahoma State University \\ Reubin McIntosh \\ Cherokee Elementary School - Muskogee School District
}

Follow this and additional works at: http://www.voicesofreform.com

\section{Recommended Citation}

Curry, K. \& McIntosh, R. (2020). Black church/school partnerships: The role of fictive kin relationships. Voices of Reform, 3(1), 10-34. Retrieved from https://www.voicesofreform.com/article/12770-black-church-schoolpartnerships-the-role-of-fictive-kin-relationships doi: 10.32623/3.00003

http://dx.doi.org/10.32623/3.00003

Revisions

Submission date: November $5^{\text {th }}, 2019$

$1^{\text {st }}$ Revision: February $3^{\text {rd }}, 2020$

Acceptance: March $4^{\text {th }}, 2020$

Publication date: May $1^{\text {st }}, 2020$ 


\title{
Black Church/School Partnerships: The Role of Fictive Kin Relationships
}

\author{
Katherine A. Curry ${ }^{1}$ \\ Reubin McIntosh ${ }^{2}$
}

\author{
${ }^{1}$ College of Education and Human Sciences \\ Oklahoma State University, United States \\ katherine.curry@okstate.edu \\ ${ }^{2}$ Cherokee Elementary School \\ Muskogee Public Schools, United States \\ reubin.mcintosh@okstate.edu
}

\begin{abstract}
This qualitative case study sought to gain a better understanding of the role of fictive kin relationships in a successful, long standing partnership between one Black Church and a high school in a high poverty, urban district in the Midwest. Four themes emerged: commitment, hope, strength, and equality. This study offers important insight into autonomy support, competence support, and relational support, key tenets of Self-Determination Theory (SDT), in fictive kin relationships within this school/community partnership. Findings support the importance of fictive kin relationships that exist within many African American communities and align with long-held traditions within the Black community. These finding build upon cultural capital embedded in African American communities by explaining how fictive kin relationships are developed within partnership efforts.
\end{abstract}

\section{Keywords}

school/community partnerships, urban schools, equity, reform, fictive kin

\section{Introduction}

Educational leaders in urban, high poverty schools face significant challenges in meeting the needs of students (Bryk, Sebring, Allensworth, Easton \& Luppescu, 2010; Fullan, 2005; Henry, 2014). These schools, many of them deemed as "failing schools" (Bryk, et al., 2010), often serve children of color living in high poverty, crime ridden neighborhoods (Henry, 2014; Hileman, Clark \& Hicks, 2012; McKinsey, 2009; Noguera, 2008). For these schools, educating students who experience poverty involves mitigating "multiple adverse synergistic risk factors" related to their home life that complicate and impede learning (Jensen, 2013, p. 25). Additionally, schools in high poverty neighborhoods are often underfunded compared to schools in more affluent 
neighborhoods, and funding in low-income Title I schools across the U.S. has decreased steadily since 2010 (Lynch, 2016) resulting in inequities at both the school and neighborhood levels. The inequities that they experience, primarily lack of resources and support, mean that students in these neighborhoods "will face a drab future if the schools continue to fail them" (Henry, 2014, p. 1).

Providing equitable learning opportunities for all students has been a primary focus of reform efforts since No Child Left Behind passed in 2001 (NCLB, 2001). A resulting reform strategy includes school/community partnerships where community members "step in" to facilitate student success (Sheldon \& Epstein, 2005). Evidence suggests that community/school partnerships can, indeed, make a difference when resources and support are scarce, especially in low income, diverse schools and that, through effective partnerships, community organizations are able to provide academic intervention to promote academic success. Benefits of effective school/community partnerships include improved student behavior and reduced discipline (Sheldon \& Epstein, 2002), higher attendance rates, enhanced social skills and student resilience, and academic gains such as increased test scores and graduation rates (Henderson \& Mapp, 2002). Additionally, when schools and communities collaborate, enhanced policies, practices, and resources often result. Resources can include higher quality learning programs for students, new resources to improve teaching and curriculum, and funding for after-school programs.

Despite known benefits of school/community collaboration, one particular type of partnership, those between schools and faith-based organizations, has not garnered substantial attention in the literature. One reason for a lack of emphasis on faith-based organization/school partnerships is that these partnerships can be controversial due to varying perceptions regarding whether faith-based organizations can effectively collaborate with schools without compromising religious identifies of participants (Loconte \& Fantuzzo, 2002). It logically follows that this perception is enhanced when the faith-based organization is a church that partners with a school to facilitate the success of students. Despite this controversy, policy leaders are often convinced of the utility of faithbased partnerships as all American Presidents since President H.W. Bush (President Bill Clinton, President George Bush, President Barack Obama, and President Donald Trump) have emphasized the importance of faith-based entity/school partnerships to enhance student outcomes (Henry, 2014).

\section{The Black Church}

The Black church has a rich, powerful, and culturally significant history in the United States (Stuckey, 2013) and has been deemed "the most important institution that has ever existed in the Black community" (Joseph, 2015). Joseph (2015) explains:

Black churches gave spiritual, religious and material sustenance to African-American communities...The Black church's radical humanism harbored a fierce resistance to slavery, a love of freedom, and a thirst for citizenship and equality that made it a hotbed of internal debates, discussions and controversies over the best course for Black liberation in America (para 2). 
The belief system of the Black church, drawn from a combination of African folklore and Christianity, emerged to help Black people survive slavery in America and its aftermath (Joseph, 2015). Since times of slavery, relationships within the Black church have brought about strength, unity and empowerment for Black Americans (Joseph, 2015; Khalifa, Dunbar, \& Douglas, 2013). Additionally, the Black church has long held a respectable reputation for being an advocate for community involvement (Logan, 2018) with the Black church continuing to inform and critically assess equality and fairness in society.

Not only do Black churches have significance for the community, Black churches hold an important place in the daily lives of many African Americans (Jordan, 2013), and they are often integrally connected to their personal identity. As a gathering place centrally located in many African American neighborhoods, the Black church has consistently been an information center for African American families. The influence of the Black church is far reaching. Black churches support all communities where African Americans reside, not just neighborhoods in close proximity to the church. In sum, the Black church's inner motivation and desire to improve society through community involvement is found in direct relation to the past racial discrimination and inequity in quality of life embedded in the threads of United States' history (Logan, 2018).

\section{Relationships and the Black Church}

A universal norm that is established in social science research is the practice of seeking assistance from family members in times of need (Ben-Porath, 1980; Coleman, 1988; Granovetter, 1973). Family members, including extended kin, comprise what most individuals perceive as their core support networks. Myroniuk, Prell, and Kohler (2015) explain, "in most cultures throughout the world, the bonds among kin are the most likely to be durable and dependable because of shared lineage and mutual loyalty" (p. 580).

However, in some instances, relationships beyond the nuclear and extended family play a significant role in child development. For example, co-parentage, existing as "godparents" in England and "compadre" in Spain (Chatters, Taylor, \& Jayakody, 1994), creates bonds between a child's biological parents and a child's ceremonial parents that involve commitments to provide emotional and material assistance (Chatters, et al., 1994). These relationships, often referred to as "fictive kin," refer to relationships between individuals who are unrelated but have a relationship that takes on the characteristics of those experienced by close family (definitions.uslegal.com, 2019).

Guttman (1976), in his work examining fictive kin relations among Black families, noted that individuals from West African cultures "viewed kinship as the normal idiom of social relations" (as cited in Chatters, Taylor, \& Jayakody, 1994, p. 298). These relations pre-date the period of slavery (Guttman, 1976) and are still quite common among African American communities (Allen, Bliesner, \& Roberto, 2011; Brooks \& Allen, 2013, 2016; Chatters, Taylor, \& Jayakody, 1994; Steward, 2007; Taylor, Chatters, Hardison, \& Riley, 2001). Many fictive kin relationships in the African American community today are developed out of need and are depended upon for support in the absence of immediate family members (Brooks \& Allen, 2016). 
Fictive kin relationships are also quite common in the Black church. In many Black churches, if a student does not have a two-parent presence at home, older African Americans in the church will "step in" to provide similar presence and support as that of a biological parent. Research suggests that fictive kin relationships can make a positive impact on the educational achievement of students, especially within younger generations as students receive emotional and academic support to persist in educational efforts (Taylor, Chatters, Woodward, \& Brown, 2013).

\section{Problem and Purpose}

While fictive kin relationships are common within the African American community, and while research suggests that they can positively influence student educational outcomes (Taylor, et al., 2013), little is known regarding how these relationships form outside of the church community and if they exist in school/church partnership efforts. Therefore, the purpose of this study was to gain a better understanding of the role of fictive kin relationships in a successful, long standing partnership between one Black church and a high school in a high poverty, urban district in the Midwest. The following research questions guide this study:

What role, if any, do fictive kin relationships have within this school/community partnership? And, if present:

1. What characteristics make fictive kin relationships distinct from other relationships within this partnership?

2. How are fictive kin relationships developed within this Black church/school partnership?

3. What needs are these relationships fulfilling for student partners?

4. What are student perceptions regarding the role that fictive kind relationships have in their success?

5. What are Black church partner perceptions regarding the role that fictive kin relationships have in student success?

\section{Theoretical Framework}

Self-determination theory (SDT) (Deci \& Ryan, 1985b, 2000, 2008) was chosen as the theoretical framework for this study because it has become known as a theory of optimal relationship development and functioning (Knee, Porter, \& Rodriguez, 2014; La Guardia \& Patrick, 2008). SDT incorporates personality, developmental, and situational influences on optimal psychological well-being of individuals (Knee, Hadden, Porter, \& Rodriguez, 2013), a psychological state that results in success in other areas of life. According to SDT (Deci \& Ryan, 1985b, 2000, 2008), being self-determined means that one operates relatively autonomously in his/her actions and that these actions are freely chosen. Further, actions that are endorsed, rather than coerced or pressured by external forces or internal expectations have the greatest likelihood for goal success (Knee, et al., 2013). This definition of what it means to operate with self-determination means that choices and behaviors are authentic and that they align with one's needs. 
Self-determination theory has utility for explaining the development of fictive kin relationships within Black church/school partnerships because participation in partnership efforts is voluntary and requires purposeful decisions to enter and remain in partnership relationships. Motivation must come from within to join partnership efforts, and need fulfillment must result in order for partners to engage in the relationship in ways that cause the relationship to deepen. Research supports the utility of SDT as a theoretical framework as fictive kin relationships are typically based on individual choice (Chambers, et al., 1994; Chatters, Taylor, \& Jayakody, 1994).

\section{Literature Review}

\section{School/Community Partnerships}

The importance of collaborative efforts between home, school, and community to enhance educational success is firmly established. Joyce Epstein (2018) states, "there is no topic in education on which there is greater agreement than the need for family and community involvement" (p. 1). Despite this agreement, approaches to relationships between families, communities, and schools have changed dramatically. What began as a discussion of "parent involvement," ways that parents and family members could be involved in activities at school or as what Jeynes (2013) describes as "demonstrable actions...like attendance at school events and reading to one's child" (para. 1), has evolved to a greater emphasis on partnership models with specific consideration of what families and community members "think, dream, and worry about" (Ferlazzo, 2011, p. 12). Redding, Langdon, Meyer, and Sheley (2004) emphasize important qualities of partnerships, versus involvement, including "building a foundation of trust and respect," (p. 1) and, thus, developing partnership ties that exist beyond the walls of the school.

The mindset regarding schools, communities, and families as "partners" is essential because it greatly enhances opportunities for schools, communities, and families to share the responsibility for educating children, promoting crucial support for students, primarily for those who lack support in their home environments. The term "partnership" includes such commonly used words as "involvement," "engagement," "participation," and "collaboration" to suggest that schools and communities share responsibilities for the education of children (Epstein, et al., 2018, p. 2). With this sharing of responsibility, it is believed that schools should become more open to the voices of families and communities. As a result, an understanding has developed that educational leaders share in the responsibility for developing a school and district culture that involves community and family members in productive ways (Epstein, et al., 2018). Perhaps one of the most important shifts in this line of research is that, in recognizing families and communities as partners, a sense of equity emerges as all members of the community are valued and have the ability to contribute to student learning.

\section{Fictive Kin}

While present in all communities, Hill (1999) identified strong non-kin relationships as an important cultural strength in African American families. Chatters, et al., (1994) found that, in a nationally representative dataset from the National Survey of Black Americans (NSBA), two out of three of the 2,107 participant African American families included fictive kin relatives. Researchers have presented three categories for the development of kinship social support: 
provision of physical and emotional care, continuity or consistency in an individual's life, and emotional investment (Howes, 1999).

For many African American families, fictive kin relationships are utilized as "an adaptive strategy that allows for the sharing of resources" (Lamborn \& Nguyen, 2004, p. 547) in the absence of, or in alignment with, biological family ties. These relationships provide emotional support needed to persist in difficult situations. For example, relationships outside of the family can help individuals cope with ongoing stresses of daily life (Benin \& Keith, 1995). They can also provide material resources such as providing a place to live when confronting homelessness (Taylor, Chatters, \& Celious, 2003) and in coping with physical and mental health problems (Cohen, Underwood, \& Gottlieb, 2000; Lincoln, 2000). According to Hall (2008), fictive kin relationships provide emotional, financial, and academic support as well as moral support in troubled times. These relationships provide a sense of identity, emotional security, care in times of crisis, and advice and guidance when confronted with chaotic home environments (Hall, 2008). Additionally, fictive kin relationships can help individuals "escape the harsh realities of their neighborhood and home" (Hall, 2008, p. 265). On the basis of findings in the literature, it follows logically that fictive kin relationships can promote healthy psychological well-being. This understanding is important because support relationships, the presence of at least one caring person in an individual's life, can provide the support needed for healthy development and learning (Werner, 1999).

\section{Fictive Kin Relationships and Education}

While the importance of fictive kin relationships as sources of social support is well established (Hatchett, Corcoran, \& Jackson, 1991; Taylor \& Chatters, 1986; Taylor \& Chatters, 1991; Stack, 1974), little is known about how these relationships influence PreK-12 education, specifically student success toward graduation from high school. A recent study on the influence of fictive kin relationships and education was conducted in 2016 by Brooks and Allen. They investigated the ways in which African American college students attending a historically Black university (HBCU) perceived fictive kin relationships and religiosity on their success in college. Findings indicate that both factors, fictive kin relationships and religiosity, helped students sustain college attendance at this HBCU. In fact, each of the 14 participants had someone in the university setting or local community, whether it was a pastor, parent-like figure, or peer, that they referred to as "family" (Brooks \& Allen, 2016). Gaining a better understanding of the role of fictive kin in student success is important as Taylor, Hinton, and Wilson (1995) assert that "to truly benefit African American children and society as a whole, the factors that contribute to positive academic experiences must be isolated and studied" (p. 294).

\section{Self-Determination Theory}

According to Self-Determination Theory (SDT) (Deci \& Ryan, 2000), individuals are motivated to purposive action when their psychological needs of autonomy, competence and relatedness are met. Need, as defined by Deci and Ryan (2002), is an internal, biological force that supplies the energy to sustain purposeful and goal directed action. Much like calories sustain physical activity, psychological needs fuel the autonomous motivation for an activity (Reeve \& Halusic, 2009; Reeve, Ryan, Deci, \& Jang, 2008). Meeting of psychological needs is essential for promoting life 
satisfaction and well-being (Deci \& Ryan, 2000), and evidence suggests that people are motivated toward actions or activities that support the satisfaction of the psychological needs of autonomy, competence, and relatedness (Deci \& Ryan, 2000; La Guardia, Ryan, Couchman, \& Deci, 2000; Vallerand, 1997).

Autonomy manifests as a cognitive belief representing individual agency and control over behavior and goals (Assor, Kaplan, \& Roth, 2002; Jang, Reeve, \& Deci, 2010). The need for autonomy is satisfied when one perceives behavior as self-endorsed or volitional (deCharms, 1976; Ryan \& Grolnick, 1986). Competence is defined as possessing the knowledge of how to master a task or activity and the confidence to apply that knowledge to achieve desired goals (Connell \& Wellborn, 1991). This need is met through the satisfaction one receives when exercising and extending personal capabilities (Deci \& Ryan, 1985; Elliott, McGregor, \& Thrash, 2002; Koestner \& McClelland, 1990). Relatedness includes feelings of security, attachment, and belonging to others as well as to organizations (Deci \& Ryan, 2002). The need of relatedness is met when one feels connected with others through relationships (Deci \& Ryan, 2000).

The utility of SDT for explaining the development of fictive kin relationships within the Black church/School partnership stems from recent applications of SDT as it has become known as a theory of optimal relationship development and functioning (Knee, Porter, \& Rodriguez, 2014; La Guardia \& Patrick, 2008). Specifically, through relationships, individuals may be motivated to persist in goal directed behavior when their psychological needs of autonomy, competence, and relatedness are met. As relationships deepen, they provide psychological well-being and motivation for success.

\section{Methods}

This study employs a case study design utilizing multiple sources of data (Yazan, 2015) including observations, participant interviews, and document analysis to gain a better understanding of the role of fictive kin relationships in partnership efforts between a Black church and high school in a large, urban school district in the Midwest.

\section{Population}

The case identified in this study is a partnership between one historically Black church and one urban high school in the second largest public-school district in a Midwestern state in the United States. The partnership has existed for over 40 years. To protect anonymity of all participants, the pseudonyms of Cornerstone Baptist Church and North High School are used.

Cornerstone Baptist Church. Cornerstone Baptist Church is home to one of the largest African American congregations in this urban area, with a weekly attendance of 650-700. The church is located in an urban neighborhood with historical significance for many African Americans. Founded in 1917, it provides a large number of ministries to its congregation and to the community including ministries for children, education, married adults, seniors, drama, finance, health, media, nursery, prayer, women, men, social service, and youth (Church Website, 2018). It employs one senior pastor and five associate ministers. It is home to a congregation of diverse ages (Personal Interview, 2017). Thirty percent of the church's membership is 50-80 years of age, and 
approximately $40 \%$ of the membership is 20-50 years of age (Personal Interview, 2017). Approximately $25 \%$ of the congregation is under 20 years of age, and 5\% is older than 80 years (Personal Interview, 2017). The church places a strong emphasis on the educational attainment of its members and has been instrumental in supporting students in K-12 grades and in college (Personal Interview, 2017). The church membership is proud of the fact that it has nurtured countless successful African American students (Personal Interview, 2017). The influence of the church is evidenced in the fact that several members of the congregation that have "grown up" in the church are now doctors, attorneys, judges, principals and teachers.

North High School. North High School is a public high school in the second largest school district of this Midwestern state. The school has a rich history and served as an all-Black high school before racial integration was enforced in the 1960s-70s (District Website, 2017). The total student population in the fall of 2016 was 1,117 (District Website, 2017). The ethnic breakdown of the student population includes: African American 41\%, Caucasian 41\%, Multiracial 7\%, Hispanic 6\%, Native American 3\%, Asian 4\% (District Website, 2017). Three of its certified teachers, one guidance counselor, and the school registrar are members of Cornerstone Baptist Church (Personal Interview, 2017). Since Fall 2016, North High has enrolled an additional 260-270 students due to a recent consolidation of schools in the district. North High School serves students in grades 9-12.

\section{The Partnership Between Cornerstone Baptist Church and North High School}

The partnership began 40 years ago when the pastor's children attended North High, and he saw the need to support African American students who had recently gone through school integration (Personal Interview, 2017). Since the partnership's beginning, there has been a close relationship between the two organizations, and consistent support has been provided to ensure effectiveness and efficiency to impact its community and families (Personal Interview, 2017).

An estimated 60 members of Cornerstone Church regularly participate, at least once per week, in the partnership with North High. A multi-faceted approach takes place to support student achievement. Most students who participate in partnership efforts are recommended by the school because they are considered "at risk" for failure to graduate. In turn, church members strive to build relationships with these students and provide the support needed for successful high school completion. Church members give of their time weekly to support reading and mathematics tutoring. Also, opportunities exist for students who are preparing for college to work with a church member to complete college applications and prepare college entrance materials and documents. Students who need someone to talk to and confide in, due to limited home support, also have time with their church partner. A few of the church members also conduct small group sessions with students. Topics addressed include drug and gang prevention, respect for members of society, communicating with law enforcement, and practices for healthy living. Church members also play basketball with students two times per week during the activity period at North High. There is a strong presence of Cornerstone members present at North High, with many church members on campus as often as three times per week. 


\section{Research Sample}

Purposeful criterion sampling (Palinkas, et al., 2015) allowed the selection of participants who could provide information-rich data (Patton, 2001). Criteria included involvement in partnership efforts for more than one year. Participants included: (a) four students 18 years of age or older who were on track to graduate in the spring of the current academic year, (b) four church members, two church leaders and two members of the congregation, and (c) four school personnel: a principal, counselor and two teachers, for a total of twelve interview participants. We purposefully chose to include students who were considered "at risk" but who also met graduation requirements so that we could understand the role of fictive kinship in their success. All participants participated in partnership efforts. Participant characteristics varied as related to their length of time as a member in the church, role in the partnership, age, and gender.

These characteristics are provided in Table 1. 
Table 1: Demographic characteristics of study participants

\begin{tabular}{lllll} 
& \multicolumn{1}{c}{ ROLE IN } & APPROXIMATE AGE & GENDER & ETHNICITY \\
\hline PARTICIPANT 1 & Student & & Male & \multicolumn{1}{c}{$\begin{array}{l}\text { African } \\
\text { American }\end{array}$} \\
PARTICIPANT 2 & Student & 18 & Female & $\begin{array}{l}\text { African/African } \\
\text { American }\end{array}$ \\
PARTICIPANT 3 & Student & 18 & African \\
American
\end{tabular}

\section{Data Collection}

Multiple data collection methods were utilized including observation, participant interviews and document analysis to provide a solid, accurate account of the case (Yazan, 2015).

Interviews. An open-ended, semi-structured interview protocol was utilized to gain participant perceptions regarding the role of fictive kin in partnership efforts. Twenty-four interviews were conducted, one initial and one follow-up interview with each participant. Field notes were taken before and after each interview, providing further understanding of participant responses.

Documents. Participants were asked to bring any artifacts to the interview that they considered to be significant to the partnership. Document analysis included documents relevant to the partnership including invitations for involvement in partnership efforts at both North High and Cornerstone Church, programs certificates, published materials such as newspaper articles, and web published information retrieved from school and church websites.

Observation. Extended observation was an instrumental part of data collection providing an indepth understanding of relationships between church members and students. Non-participatory observations were made at all times during the school day: before school, activity period, lunch time, and after school. Observations on the church campus occurred during scheduled partnership activities after school and evening, church services, and individual mentor/mentee tutoring sessions. School campus observations included tutoring sessions, mentor and student interactions during activity periods, and intervention strategies to improve student literacy. Intervention 
strategies involved Cornerstone Church members giving of their time to perform small group instruction to students with a district approved literacy curriculum, Reading Partners, to support reading comprehension. Collectively, approximately forty hours were spent in observation of partnership efforts.

\section{Data Analysis}

Data analysis began simultaneously with data collection, following a constant comparative approach (Merriam \& Tisdell, 2015). Data analysis followed an inductive method, involving "consolidating, reducing, and interpreting what people have said and what the researcher has seen and read [for] the process of making meaning" (Yazan, 2015, p. 148). Some responses to interview questions elicited long, personal stories from participants. Metaphors and figurative language were found in responses to interview questions. Data of this comprehensive nature required thorough review and analysis throughout the coding process (Yazan, 2015). Analysis of data began in an inductive manner (Yi, 2018) utilizing open coding. Initial categories were formed by breaking down, comparing and conceptualizing data. Once categories were formed, data were analyzed to identify themes that emerged across categories (Yi, 2018). Member checking was performed (Saldaña, 2015) to enhance overall trustworthiness of the findings. Credibility is established through systematic search for competing explanations and interpretations.

\section{Findings}

Four themes emerged from data analysis: commitment, hope, strength, and equality. Each theme emerged in documents, verbal responses articulated through participant interviews, and in observations of partnership interactions. Participants were quick to identify fictive kin relationships in partnership efforts, to disclose their perceptions of fictive kin relationships, to describe how fictive kin relationships emerged, and to explain how relationships are maintained through the partnership. They spoke boldly, and each participant's response was consistent with each of the themes identified in the study. It was also noted that the roles of church and school partners differed in partnership efforts. Church partners "stepped in" and developed relationships with students in an effort to provide needed support for success. School partners, in contrast, supported partnership efforts by recommending students to the partnership and providing accessibility and support for facilitation of partnership activities.

Commitment. Participants explained the development and sustainability of fictive kin relationships. Each of the student participants spoke of the commitment of their partners with which they developed a fictive relationship. One female student participant stated:

My [fictive] sister is always here to support me when I call her. I can call her or send a text and she always responds to me. I really feel as if she wants me to be great in school. I believe honesty that I am able to graduate on time, because I had my sister. 
The participant continued,

... and my sista recently graduated from college, and she has worked to get me a scholarship through her sorority. She wants me to pledge so that I will have a larger sisterhood in college, meaning her Greek sorority... I mean my sista always tell[s] me to stay the course.

When asked about what "staying the course" means, the participant shared, "I believe it means that I will persevere and do whatever it takes to succeed." Another student explained the strong bond he shares with his fictive brother. He stated,

My brother, he is the brother that I never had and one that I always wanted. I guess like other people say "a brother from another mother." He is only three years older than me, but he is in college. The experiences that he gained are helping me not only prepare for college but [are helping me to] understand that even though I struggle with math, I can make it in college. There are things out there to help out. Boy, I needed to hear this from my bro...real talk! He always makes himself available to help with all of my schoolwork and makes sure that I keep up with college applications and the due dates. He always says you have to be committed to whatever you do... I always respond, "I know."

Not only were fictive brother/sister relationships present in partnership efforts, fictive parent relationships were present as well. One student replied,

My mentor calls me "son," and since we have formed a bond over the past four years, I call him "pops." He is like a father to me. He always looks out for me and won't allow me to give up. He tells me that he is committed to making sure I do what I am supposed to everyday. My biological father passed away a few years back. I really respect him and I look to him as a father figure.

This student participant went on to say,

It is hard to endure the pain sometimes especially because my real dad was always at all of my football games for school. I could always count on him to come through. I can now count on my mentor to be that fatherly person whom I have grown to love over the past three years. He always expresses great interest in my life and where I am headed. He does not hold back when it comes to telling me right and wrong. I know sometimes, I am stubborn, but hey... what teenager doesn't make mistakes, you know? Just like he tells me to be committed, I see that he is committed to me too.

Church partners further supported the importance of commitment to develop fictive kin relationships. When asked how these relationships had formed, one church partner explained, 
This idea has been passed down to me by my parents and grandparents who were alive during the reconstruction era in our nation. Our people need committed relationships to be successful. They need someone who looks like them and can mirror or support in ways that only biological relationships do.

Another church participant indicated her commitment as we waited for students to come into the learning lab for an after school tutoring session. She stressed,

My commitment is to ensuring our "babies" have what they need to be successful. They need love and someone to care for them. I know that many of our young Black children have broken homes, and they need another person who is relentless and will ensure that they have anything they need to succeed.

Observations before school emphasized the commitment required to sustain fictive kin relationships. Many church partners arrived 15 to 20 minutes early and were ready to greet their fictive family member as he/she arrived at school. If a church partner was going to be absent, the church partner contacted the student to let him/her know. One student explained, "my mentor always calls me and lets me know ahead of time if they could not make it. Many times, my [fictive] sister comes and meets me on the weekends or in the evening."

North High partners also confirmed the importance of commitment in forming strong relationships. One school partner commented that the fictive relationships develop over time. She continued,

The longer a partnership is in place, the stronger the relationship. When a student sees a highly respected person in their community who also expresses interest in them and their school and academics, it really strengthens their ability to engage.

Hope. The theme of "hope" emerged as an important factor in fictive kin relationships. Church partners expressed that instilling hope is their motivation to deepen the relationship with students. Additionally, the increasing need for hope to improve student motivation was deeply embedded within the school partners' desire to continue this partnership from year to year. One school partner shared,

We have quite a daunting task as school leaders, who do not look like many of our students.....to show them that they can be successful and give them hope because there are members of the community who look like them that are successful and want the same for them. I can tell how students have more hope and encouragement with their fictive kin relationships.

Church partners believed that hope was important for students as they matriculate through school and enter young adulthood and college. One Cornerstone partner stated, "in a world of hopelessness, we must be the one positive and affirming voice and support for our young black boys and girls." A second Cornerstone partner added, 
We must love everyone. A part of loving everyone is ensuring that we mend the broken-hearted. We can ensure this by developing these relationships with our young people... and honestly this gives them some hope for a brighter day, year and life.

A school partner stated, "It is through fictive relationships that many students get the hope they need for tomorrow."

One church partner specified characteristics of fictive kin relationships. He explained, "There is hope and genuine love at the core of fictive relationships. They need hope, some young people are displaced and are looking to find themselves and are hopeless."

Strength. Findings indicate that students and Church members have a sense of internal strength that motivates them to seek success beyond circumstances in their immediate community. One church partner shared, "because we are strong as a church we want to communicate and embark this same level of strength to our young people so they can do and they can be successful." Another church partner expressed,

We take time to make sure that we share our personal problems, challenges and issues and how we faced them, how we did not let them rule us and how we overcome in order to better prepare our young people for the world that awaits them... and [encourage them to] be strong.

School participants expressed the presence of strength in fictive kin relationships as we walked through the school and observed students working with their fictive family members. One school partner stated, "the academic component of this partnership is working to provide additional academic support which strengthens a student's proficiency for on grade level functioning. I have seen how the students in the partnership improve their outlook on life." Another North High participant shared, "each student has been able to strengthen their overall perceptions regarding their future. There is a strong amount of self-determination that we have found within students who are actively involved with the partnership." School partners agreed that, "this partnership works to strengthen the entire community."

Equity. The theme of a desire for equity had an instrumental effect on the establishment and continuity of North High's partnership with Cornerstone Baptist Church. One student participant shared,

my [fictive] sister shares with me about the past injustices that have been ...I see them myself when I look at the news and then when we talk about many of the racial differences in my history courses. I have seen how our race turns against one another but there are still many Blacks that are fighting daily for everyone to be equal.

School partners expressed that teachers and staff at North High are committed to providing opportunities to ensure equity in daily instructional practices for all learners. A school partner stated, "equity is a core foundation by which our mission statements and vision statements were 
created." To this school partner, the desire for equity was a key factor for support of partnership efforts. Between interview sessions as two participants met in the hallway, one school partner expressed, while another school partner nodded in agreement,

We believe firmly that all students are created equal, and we must continue this partnership in order to further improve social and emotional development for African American students who come from emotionally and socially economically diverse backgrounds. Partnership efforts help us reach this goal.

Even though school partners press for equity, the establishment of fictive kinship relationships surprises school partners at North High. One North High partner shared,

We have not forced fictive kinships in partnership efforts. We are so thankful that no matter how challenging a situation, the students always have some sort of fictive kinship by the end of each academic year. There is a deep desire of church members to improve equity or demand it for younger Blacks and minorities.

One student participant in the study brought in a photo album of a tour of a historically Black college that he and his fictive father had attended. Pictures that he shared depicted himself and his fictive father, and they included other students at North High with their mentors and fictive family members. This participant explained the "great time" he had shared with his fictive father. He stated,

I was able to learn on the trip that our opportunity to be educated as Blacks were not always equal to that of Whites. We studied this in my history class, but I was able to see firsthand from speaking to different college people. They shared with me how Black people were treated and how [HBCU] colleges provide a way for Blacks to get their education after high school.

For this student, the opportunity to experience a college visit with his fictive father and hear from college personnel about inequities in the past helped him to understand some of the challenges he was facing, and it helped him understand opportunities for challenging those inequities.

This theme was further supported as another student shared that his fictive brother goes to an HBCU. He explained, "there is an underlying basis for restoring lost equity and respect for the African American race that many other colleges do not have. I am looking at going to his college next year...I'm excited!" Regarding student perceptions of the role that fictive kin relationships have in student success, each student shared that he/she has the opportunity to be successful in ways that would not be possible if the partnership with Cornerstone Church members were not in place.

Observations of partnership events at North High included church participants providing their fictive family members funding for books and supplies for school, ACT and SAT test vouchers, or letters of recommendation for college applications. Each of these acts of kindness works 
collectively to provide students at North High with, "a fair and equal opportunity to succeed," as one of the school partners from North High explained. Equitable learning experiences and providing resources through relationships with young African Americans drives the pastors at Cornerstone to continue in partnership efforts. A church partner explained, "We are obligated, and I feel called by God to continue the support to our schools. Our schools are not equal." Another Cornerstone participant continued, "We fail our children if we do not fight for them for equal opportunity and resources."

Findings indicate that the factors of commitment, hope, strength and equity work together for the formation and sustainability of fictive kin relationships. These relationships supported student motivation and achievement as they worked to reach academic goals. The following section discusses each of these themes through the lens of Self-Determination Theory to provide further understanding of how student motivation is enhanced through fictive kin relationships.

\section{Discussion}

Each of the themes is discussed in relation to research questions and through the lens of SelfDetermination Theory. SDT (Deci \& Ryan, 2000) explains that people are motivated toward actions or activities that support the satisfaction of the psychological needs of autonomy, competence, and relatedness (Deci \& Ryan, 2000; La Guardia, Ryan, Couchman, \& Deci, 2000; Vallerand, 1997). Our findings suggest that the psychological needs of students were met through partnership relationships.

Research Question 1: What characteristics make fictive kin relationships distinct from other relationships within this partnership?

Findings indicate that fictive kin relationships were present in partnership relationships. We purposefully chose to include students who were "at risk" so that we could understand the role of fictive kin in their success. Many students in this school, and most students in this partnership, face challenges that put them "at risk" for failure to complete high school graduation requirements, it was important to understand the types of relationships that made a difference for these partner students. The defining characteristic of fictive kin relationships was the amount of commitment required to develop and sustain relationships. Regardless of the type of relationship, sibling or parent/child, all partners understood the importance of commitment. Students were able to articulate the commitment that their church partner had made to them. They expressed sincere appreciation for the time, energy, expertise, and enthusiasm that these partners showed. As explained by Self-Determination Theory (SDT), these relationships communicated a confidence in student ability to succeed. This competence-supportive relationship helped students to learn to "believe in themselves" (Personal Interview, 2017) even in areas that had proven particularly challenging. Competence support looked different for different students. For some students, it took the form of tutoring and support for academic achievement. For others, competence support was manifested in the belief that the student could uphold the responsibilities required to be successful in school: arriving on time, strong school attendance, completing homework, and independent thinking. For others, competence support was manifested through extended time interacting in 
informal ways. To these students, spending time together communicated that the adult partner "likes to be with me and believes in me" (Personal Interview, 2017).

In addition to competence support, fictive kin relationships promoted a relationally supportive environment. These relationships became pivotal to student success, as students relied on their mentor for encouragement, consistency, emotional support, social development, and opportunities to view situations in new and different ways. For example, consistency in the father/son relationship with the young man who had previously lost his father provided a foundation for the student to heal from his loss and to find comfort and support from an older, adult male. Both partners recognized the amount of commitment required for this relationship to develop as the student "worked through some of the pain of losing a parent" (Personal Interview, 2017).

Research Question 2: How are fictive kin relationships developed within this Black church/school partnership?

SDT explains the formation of fictive kin relationships through autonomy support. Students and partners engaged in these relationships voluntarily. As relationships deepened, the commitment to continue deepened also. Students were well aware that church members volunteered their time because of deep care and concern for the student. Church members also realized that students engaged voluntarily, and their commitment to "being there when he/she needs me" (Personal Interview, 2017) helped to solidify these voluntary relationships.

Competence support also explains the formation of fictive kin relationships. As church partners invested time into their relationships with student partners, students began to understand the commitment that church partners had made to them, and they began to "believe in themselves" (Personal Interview, 2017). Church partners encouraged these students even in areas that had proven particularly challenging. Each student had different needs, and as explained previously, competence support looked different for different students. However, the encouragement provided to these students and the consistency of relationships helped to promote student efficacy for reaching educational goals.

Another factor that seemed to support the development of fictive kin relationships was the flexibility and accessibility provided in partnership efforts. School partners facilitated the partnership by welcoming and inviting church partners on campus (Personal Interview, 2017). The school "opened its doors" to church partners before, during and after school, and a variety of opportunities for interaction were offered. Additionally, the church provided multiple opportunities for support outside of school hours. Students were welcomed on the church campus, whether they were members of the church or not, to receive the support and assistance that they needed for success.

\section{Research Question 3: What needs are these relationships fulfilling for student partners?}

Needs varied by student; however, the answer was found in the themes of hope, strength, and equity. Whether students were struggling with failing grades, suffering from the loss of a parent, or discouraged because of stressful home environments, each student benefited from the hope that fictive kin relationships provided. Church members explained that hope was manifested through 
encouraging students to "see beyond their immediate situations" (Personal Interview, 2017). Through SDT, this finding can be explained as competence supportive and autonomy supportive. Students who were encouraged to alter their perceptions of their current situations, to see opportunities that exist beyond their current situations, began to believe that they did have the needed skills and abilities to succeed. They became hopeful that opportunities awaited them and that they could find success despite their current challenges. Additionally, as church members helped students understand the strength of their heritage and discover hidden strength within themselves, students gained confidence in their abilities to address their challenges, and they began to explain feelings that aligned with liberation from oppressive circumstances. They began to see themselves differently: as stronger, more capable, and with the independence to make decisions for themselves.

SDT explains the theme of equity through competence support, autonomy support and relational support. Competence support was established when students realized that church members were motivated to enhance equity by providing resources for success. They began to believe in themselves when church members pushed for equitable circumstances. Autonomy support was provided as church members respected the feelings, emotions, attitudes, and challenges that students experienced. Church members helped students "work through their challenges" in ways that benefitted the student. Concerning relational support, as church members provided opportunities or engaged in discussions that promoted equity, students began to understand the care and concern that their mentors had for them. Church members explained that their motivation to serve these students came from religious convictions and the desire to share values and skills that had led to their own success. It was evident to students that church members were motivated to seek the good of the students by helping them understand their current situations and helping them find answers for the challenges they faced.

Research Questions 4 and 5: What are student perceptions regarding the role that fictive kin relationships have in their success? What are Black church partner perceptions regarding the role that fictive kin relationships have in student success?

Findings suggest that fictive kin relationships developed through a strong sense of commitment, shared beliefs about the need for hope and the strength inherent in the African American community, and a press for equity. Each partner expressed fictive kin relationships as absolutely essential for student success. Fictive kin relationships were credited for supporting student success in the face of oppressive conditions, such as: poverty, homelessness, divided families, food scarcity, and lack of successful role models. Students articulated the importance of fictive kin relationships through comments such as "I don't know what I would have done without [name of mentor]" or "[name of mentor] believed in me when no one else did." Church members expressed the importance of fictive kin relationships in comments such as "Our people need committed relationships to be successful. If a child does not have the support they should to be successful, we really are not doing them the best services," and "My commitment is to ensuring our 'babies' have what they need to be successful....many of our young Black children have broken homes, and they need another person who is relentless and will ensure that they have anything they need to succeed." 
School partners supported the autonomous development of fictive kin relationships. One school partner stated,

We have not forced fictive kinships from the school's standpoint in the partnership efforts. We are so thankful that no matter how challenging a situation, the students always have some sort of fictive kinship quality by the end of each academic year.

The perception of the importance of development of strong relationships was the motivating factor for school participants to continue partnership efforts. These relationships helped school partners reach educational goals in some of the most challenging situations.

\section{Implications and Recommendations}

The tradition of fictive kin has been passed from generation to generation in many African American communities and continues to hold an essential place in the lives of African Americans. What is important from these findings is that evidence suggests the development of fictive kin relationships through church/partnership efforts.

\section{Implications for Practice}

In relation to practice, these findings underscore the importance of relationship building in partnership efforts (Sheldon \& Epstein, 2005). School partners in this study provided time and space for church partners to meet with involved students before and after school and during the school day. Church partners were eager to participate in partnership efforts because of their commitment to student success at this high school, and even though most of the students were not members of the church, this partnership allowed them to connect to caring adults who "were determined to make a difference" (Personal Interview, 2017). The result was that scarce resources in this high school were supplemented through partnership efforts as school partners desired to "provide all that these student need for success" (Personal Interview, 2017). The partnership connected students to church partners who shared important resources, provided encouragement, served as role models, and promoted success. Relationships went beyond academic success to promote life skills and resilience for successful completion of high school. Though not generalizable, these findings provide insight into partnership studies that have, historically focused primarily on task goals. Our findings suggest that, without relationships, the efforts in this partnership may not have proven successful. Additional research could help provide further insight into this finding.

Further, evidence in the literature suggests that partnership efforts are often challenging for school leaders to sustain, especially partnerships that influence student performance, such as high school completion in this study. This partnership has withstood the test of time and has promoted the success of many young African American students in this community over the span of four decades (Personal Interview, 2017). These findings suggest that these partnership efforts replicated cultural norms within this community, and likely, this replication promoted success and sustainability of partnership efforts. Specifically, by replicating and enforcing healthy cultural norms, students "recognized themselves" in partnership efforts. Therefore, they were more 
inclined to persist, and relationships deepened. The integration of community cultural norms through relationship building influenced students to persist and, ultimately, reach educational goals.

Another significant contribution of this study is that it provided an understanding of factors, commitment, hope, strength, and equity, that were instrumental in the development of fictive kin relationships. These relationships were essential for success, and whether the relationship took the form of a sibling or a parent, these factors were present and promoted "buy in" from both the student and the church member. Students were deeply concerned about finding an adult who would demonstrate commitment. Additionally, the values of hope, strength and equity were important to students. Partnership efforts demonstrated and supported these values, and students persisted in partnership efforts.

\section{Implications for Theory}

This study is important because it provides an understanding of how student psychological needs may be met through partnership efforts. According to Deci and Ryan (2001), individuals are motivated toward goal pursuit when their needs for competence, autonomy, and relatedness are met. These partnerships that developed into fictive kin relationships seemed to motivate students through the fulfillment of each of these psychological needs. These findings suggest that partnership efforts provided competence support, autonomy support, and relatedness support. Students began to "see themselves differently," and they were motivated to reach academic goals. The use of this theory helped to explain effective partnership efforts by providing a lens regarding how relationships motivated students toward success, and this work may provide a foundation for future research regarding successful school/community partnerships that meet student psychological needs.

\section{Implications for Research}

It was previously noted that limited research exists regarding school partnerships with faith-based organizations (Loconte \& Fantuzzo, 2002). However, faith-based organizations are often a key component of students' lives. Findings from this study, importantly, align with critical and longheld traditions within the Black community. They suggest that this partnership built upon the cultural capital of this African American community by offering opportunities for students to develop meaningful relationships, with many of the relationships developing into "family-like" relationships, and they align with Joseph's (2015) interpretation of the importance of the Black church. Joseph (2015) states, "the contemporary Black church continues in its rich tradition of providing material benefits, community organizing and spiritual renewal for a community that remains scarred by a secular world ..." (para. 9).

An awareness of and further investigation into the vast cultural resources embedded in the African American community is important. A better understanding of the importance of the Black church for community advancement and preservation can help to promote success and upward mobility for African Americans. 
Symbolically, the Black church has always represented more than a house of worship. Metaphorically, it has represented the protector of black bodies, the educator of black girls and boys, and the audacious voice that believes, even now and against all evidence to the contrary, that [all] African-American lives matter ....(Joseph, 2015, para. 10).

Research that investigates partnerships that align with important community resources, such as the Black church, and seeks to find ways to mobilize these resources may, ultimately, empower reform that truly promotes student success for under-resourced and under-served students.

\section{References}

Allen, K. R., Blieszner, R., \& Roberto, K. A. (2011). Perspectives on extended family and fictive kin in the later years: Strategies and meanings of kin reinterpretation. Journal of Family Issues, 32, 1156-1177. doi: 10.1177/0192513X11404335

Assor, A., Kaplan, H., \& Roth, G. (2002). Choice is good, but relevance is excellent: Autonomy-enhancing and suppressing teacher behaviours predicting students' engagement in schoolwork. British Journal of Educational Psychology, 72(2), 261-278.

Ben-Porath, Y. (1980). The F-connection: Families, friends, and firms and the organization of exchange. Population and Development Review, 6(1), 1-30.

Benin, M., \& Keith, V. M. (1995). The social support of employed African American and Anglo mothers. Journal of Family Issues, 16, 275-297.

Brooks, J. E., \& Allen, K. R. (2016). The influence of fictive kin relationships and religiosity on the academic persistence of African American college students attending an HBCU. Journal of Family Issues, 37(6), 814-832.

Bryk, A. S., Sebring, P. B., Allensworth, E., Luppescu, S., \& Easton, J. Q. (2010). Organizing schools for improvement: Lessons from Chicago. Chicago, IL: University of Chicago Press.

Chatters, L. M., Taylor, R. J., \& Jayakody, R. (1994). Fictive kinship relations in black extended families, Journal of Comparative Family Studies, 25(3), 297-312.

Coleman, J. S. (1988). Social capital in the creation of human capital. American Journal of Sociology, 94, S95-120.

Deci, E. L., \& Ryan, R. M. (1985). Intrinsic motivation and self-determination in human behavior. New York, NY: Plenum.

Deci, E. L., \& Ryan, R. M. (2000). The "what" and "why” of goal pursuits: Human needs and the self-determination of behavior. Psychological Inquiry, 11, 227-268.

Chatters, L. M., Taylor, R. J., Jackson, J. S., \& Lincoln, K. D. (2008). Religious coping among African Americans, Caribbean Blacks, and non-White Hispanics. Journal of Community Psychology, 36, 371-386. doi: 10.1002/jcop. 20202

Cohen, S., Underwood, L. G., \& Gottlieb, B. H. (Eds.). (2000). Social support measurement and intervention: A guide for health and social scientists. New York, NY: Oxford University Press.

Connell, J. P., \& Wellborn, J. G. (1991). Competence, autonomy, and relatedness: A motivational analysis of selfsystem processes.

DeCharms, R. (1976). Enhancing motivation: Change in the classroom.

Deci, E. L., \& Ryan, R. M. (1985). The general causality orientations scale: Self-determination in personality. Journal of Research in Personality, 19(2), 109-134.

Deci, E. L., \& Ryan, R. M. (Eds.). (2002). Handbook of self-determination research. Rochester, NY: University of Rochester Press.

Deci, E. L., \& Ryan, R. M. (2008). A macro-theory of human motivation, development and health. Canadian Psychology, 49, 182-185. doi: 10.1037/a0012801

Elliot, A. J., McGregor, H. A., \& Thrash, T. M. (2002). 16: The need for competence. Handbook of SelfDetermination Research, 361-388.

Epstein, J. (2019). Introduction. In Epstein \& Associated (Eds.). School, Family, and Community Partnerships: Your Handbook for Action ( $4^{\text {th }}$ ed). Thousand Oaks, CA: Corwin.

Ferlazzo, L. (2011). Involvement or engagement? Educational Leadership, 68(8), 10-14. 
Fullan, M. (2005). Turnaround leadership. The Educational Forum, 69(2), 174-181.

Granovetter, M. (1973). The strength of weak ties. American Journal of Sociology, 78(6), 1360-1380.

Grolnick, W. S., \& Ryan, R. M. (1987). Autonomy in children's learning: An experimental and individual difference investigation. Journal of Personality and Social Psychology, 52(5), 890.

Gutman, H. G. (1976). The Black family in slavery and freedom, 1750-1925. New York, NY: Random House.

Hall, J. C. (2008). The impact of kin and fictive kin relationships on the mental of black adult children of alcoholics. Social Work Publications and Other Works. Retrieved from https://trace.tennessee.edu/utk_socipubs/28/

Hatchett, S. L., Cochran, D. L., \& Jackson, J. S. (1991). Family life. In J. S. Jackson (Ed.), Life in Black America (pp. 46-83). Newbury Park, CA: Sage.

Henderson, A. T. \& Mapp, K. L. (Eds.) (2002). A new wave of evidence: The impact of school family, and community connections on student achievement. Austin, TX: National Center for Family and Community Connections with Schools, Southwest Educational Development Laboratory.

Henry, L. M. (2014). Just love: A collaborative evaluation of a faith-based school-family-community partnership through the voices of the children.

Hileman, J., Clark, J. J., \& Hicks, A. (2012). Educating Black and Latino males striving for educational excellence and equity. King of Prussia, PA: American Reading Company.

Hill, R. B. (1999). The strengths of African American families: Twenty-five years later. New York, NY: University Press of America.

Howes, C. (1999). Attachment relationships in the context of multiple caregivers. In J. Cassidy \& P .R. Shaver (Eds.), Handbook of attachment: Theory, research, and clinical implications (pp. 671-687). New York, NY: Guilford Press.

Jang, H., Reeve, J., \& Deci, E. L. (2010). Engaging students in learning activities: It is not autonomy support or structure but autonomy support and structure. Journal of Educational Psychology, 102(3), 588.

Jensen, E. (2013). How poverty affects classroom engagement. Educational Leadership, 70(8), 24-30.

Jeynes, W. H. (2013). Father involvement, African Americans, and reducing the achievement gap. In Father involvement in young children's lives (pp. 71-87). Springer, Dordrecht.

Jordan, J. H. (2013). Black Americans 17th century to 21st century: Black struggles and successes. Trafford Publishing.

Joseph, P. E. (2015). Why the Black church has always mattered. Retrieved October 4, 2019, from https://www.theroot.com/why-the-black-church-has-always-mattered-1790860217

Khalifa, M., Dunbar, C., \& Douglas, T. R. (2013). Derrick Bell, CRT, and educational leadership 1995present. Race Ethnicity and Education, 16(4), 489-513.

Knee, C. R., Hadden, B.W., Porter, B., \& Rodriguez, L.M. (2013). Self-determination theory and romantic relationship processes. Personal and Social Psychology Review, 17(4), 307-314.

Knee, C. R., Porter, B., \& Rodriguez, L. M. (2014). Self-determination and regulation of conflict in romantic relationships. In Human motivation and interpersonal relationships (pp. 139-158). Springer, Dordrecht.

Koestner, R., \& McClelland, D. C. (1990). Perspectives on competence motivation.

La Guardia, J. G., \& Patrick, H. (2008). Self-determination theory as a fundamental theory of close relationships. Canadian Psychology, 49, 201-209. doi: 10.1037/a0012760

La Guardia, J. G., Ryan, R. M., Couchman, C. E., \& Deci, E. L. (2000). Within-person variation in security of attachment: A self-determination theory perspective on attachment, need fulfillment, and well-being. Journal of Personality and Social Psychology, 79, 367-384. doi: 10.1037/0022-3514.79.3.367

Lamborn, S. D., \& Nguyen, D. T. (2004). African American adolescents' perceptions of family interactions: Kinship support, parent-child relationships, and teen adjustments. Journal of Youth and Adolescence, 33, 547-558.

Lincoln, K. D. (2000). Social support, negative social interactions, and psychological well-being. Social Service Review, 74, $231-252$.

Loconte, J., \& Fantuzzo, L. (2002). Churches, charity and children: How religious organizations are reaching America's at-risk kids. Retrieved from http://baylor.edu/content/services/document.php/24229.pdf

Logan, S. (2018). The Black family: Strengths, self-help, and positive change. Routledge.

Lynch, M. (2016). Poverty and school funding: Why low-income students often suffer. Retrieved January 15, 2020, from https://www.theedadvocate.org/poverty-and-school-funding-why-low-income-students-often-suffer/

McKinsey \& Company (2009). The economic impact of the achievement gap in America's schools. McKinsey \& Company Social Sector Office. Retrieved fromhttp://mckinseyonsociety.com/downloads/reports/Education/achievement_gap_report.pdf

Merriam, S. B., \& Tisdell, E. J. (2015). Qualitative research: A guide to design and implementation. John Wiley \& Sons. 
Moolenaar, N. M., \& Daly, A. J., (2012). Social networks and education: Exploring the social side of the reform equation. American Journal of Education, 119(1), 1-6.

Myroniuk, T. W., Prell, C., \& Kohler, H. (2015). Why rely on friends instead of family? The role of exchanges and civic engagement in a rural sub-Saharan African context. African Studies, 76(4), 579-596.

Noguera, P. (2008). The trouble with Black boys and other reflections on race, equity, and the future of public education. San Francisco, CA: Wiley \& Sons.

Palinkas, L. A., Horwitz, S. M., Green, C. A., Wisdom, J. P., Duan, N., \& Hoagwood, K. (2015). Purposeful sampling for qualitative data collection and analysis in mixed-method implementation research. Administration and Policy in Mental Health and Mental Health Services Research, 42(5), 533-544.

Patton, M. Q. (2002). Qualitative research and evaluation methods (3rd ed.). Thousand Oaks, CA: Sage.

Redding, S., Langdon, J., Meyer, J., \& Sheley, P. (2004). The effects of comprehensive parent engagement on student learning outcomes. American Educational.

Reeve, J., \& Halusic, M. (2009). How K-12 teachers can put self-determination theory principles into practice. Theory and Research in Education, 7(2), 145-154.

Reeve, J., Ryan, R. M., Deci, E. L., \& Jang, H. (2008). Understanding and promoting autonomous self-regulation: A self-determination theory perspective. Motivation and Self-Regulated Learning: Theory, Research, and Applications, 223-244.

Ryan, R. M., \& Deci, E. L. (2000). Self-determination theory and the facilitation of intrinsic motivation, social development, and well-being. American Psychologist, 55(1), 68.

Ryan, R. M., \& Deci, E. L. (2001). On happiness and human potentials: A review of research on hedonic and eudaimonic well-being. Annual Review of Psychology, 52(1), 141-166.

Ryan, R. M., \& Grolnick, W. S. (1986). Origins and pawns in the classroom: Self-report and projective assessments of individual differences in children's perceptions. Journal of Personality and Social Psychology, 50(3), 550 .

Saldaña, J. (2015). The coding manual for qualitative researchers. Sage.

Sheldon, S. B. \& Epstein, J. L. (2002). Improving student behavior and school discipline with family and community involvement. Education and Urban Society, 35(1). 4-26.

Sheldon, S. B. \& Epstein, J. L. (2005). Involvement counts: Family and community partnerships and mathematics achievement. Journal of Educational Research, 98(4), 196-207.

Stack, C. B. (1974). All our kin: Strategies for survival in a Black community. New York, NY: Harper and Row.

Steward, A. (2007). Art therapy intervention with "at-risk" adolescent boys: Effects on self-image and perceptions of loss (Doctoral dissertation, State University of New York at Buffalo).

Stuckey, S. (2013). Slave culture: Nationalist theory and the foundations of Black America. Oxford University Press.

Taylor, L. C., Hinton, I. D., \& Wilson, M. N. (1995). Parental influences on academic performance in AfricanAmerican students. Journal of Child and Family Studies, 4(3), 293-302.

Taylor, R. J. (1988). Correlates of education, income, and poverty among aged blacks. The Gerontologist, 28, 435441.

Taylor, R. J., \& Chatters, L. M. (1991). Extended family networks of older black adults. Journal of Gerontology, 46(4), S210-S217.

Taylor, R. J., \& Chatters, L. M. (1986). Patterns of informal support to elderly black adults: Family, friends, and church members. Social Work, 31(6), 432-438.

Taylor, R. J., Chatters, L. M., \& Celious, A. (2003). Extended family households among Black Americans. African American Research Perspectives, 9(1), 133-151.

Taylor, R. J., Chatters, L. M., Hardison, C. B., \& Riley, A. (2001). Informal social support networks and subjective well-being among African Americans. Journal of Black Psychology, 37, 439-463. doi: 10.1177/0095798401027004004

Taylor, R. J., Chatters, L. M., \& Lincoln, K. D. (1999). African American religious participation: A multi-sample comparison. Journal for the Scientific Study of Religion, 38, 132-145.

Taylor, R. J., Chatters, L. M., Woodward, A. T., \& Brown, E. (2013). Racial and ethnic differences in extended family, friendship, fictive kin, and congregational informal support networks. Family Relations, 62(4), 609624.

Taylor, R. J., Chatters, L. M., Woodward, A. T., \& Brown, E. (2013). Racial and ethnic differences in extended family, friendship, fictive kin, and congregational informal network supports. Family Relations, 62(4), 609624. 
Vallerand, R. J. (1997). Toward a hierarchical model of intrinsic and extrinsic motivation. In M. P. Zanna (Ed.), Advances in experimental social psychology, (Vol. 29, pp. 271-360). San Diego, CA: Academic Press.

Werner, E. E. (1999). Can we apply resilience? In M. D. Glantz \& J. L. Johnson (Eds.), Resilience and development: Positive life adaptations, longitudinal research in the social and behavioral science (pp. 259-268). New York, NY: Kluwer Academic/Plenum Publishers.

Yazan, B. (2015). Three approaches to case study methods in education: Yin, Merriam, and Stake. The Qualitative Report, 20(2), 134-152.

Yi, E. (2018). Themes don't just emerge: Coding the qualitative data. Retrieved October 4, 2019, from https://medium.com/@projectux/themes-dont-just-emerge-coding-the-qualitative-data-95aff874fdce 